\title{
EPITHELIAL DYSTROPHY OF THE CORNEA
}

\author{
BY
}

Harry Friedenwald, M.D. and Jonas S. Friedenimald, M.D. Baltimore, Ma., U.S.A.

UNDER the name Dystrophia Epithelialis Corneae, Fuchs ${ }^{(1)}$ has described a clinical condition characterized as follows: (1) The disease attacks elderly persons and is slowly progressive; (2) no inflammatory symptoms accompany the progress of the lesion; (3) there is a diffuse opacity of the cornea, most intense in the central region, shading off to a clear zone near the margin ; $(4)$ the corneal epithelium is roughened, deficient in lustre, and contains numerous vescicle-like elevations.

In recent years with the aid of the corneal microscope a group of cases presenting quite a different picture has been described by

- $\operatorname{Vogt}^{(13)}$ and his pupil, Moeschler ${ }^{(14)}$, in which small dew-drop-like elevations were observed on the posterior surface of the cornea. In the November, 1924, issue of this journal, Basil Graves ${ }^{(15)}$ has published an extensive study of these changes. They consist essentially in the presence, just under the corneal endothelium, of minute clear deposits which result in slight dome-like elevations of the endothelium. When seen in smallest number they occur only in the central part of the cornea. Sometimes, however, these elevations are scattered over almost the whole posterior surface of the cornea and in some such cases he has noted the transient appearance of vacuoles in the corneal epithelium. Mr. Graves mentioned the possibility of a relation between the condition which he describes and the epithelial dystrophy of Fuchs, but had not had the opportunity to confirm this view.

In the past few years we have had under our observation five cases showing these endothelial changes. We have been able also to study three cases of typical epithelial dystrophy. All three of these cases showed, in addition to the epithelial change, extensive alterations of the endothelial surface of the cornea, similar to those described by Mr. Graves and observed by us in the other cases.

\section{GROUP I.}

Cases showing changes in the endothelial layer of the cornea, but no alteration of the epithelium

Mr. Graves has described the changes in the inner layers of the cornea in such thorough manner that there is no need for us to give in detail the appearance of those cases in which endothelial changes alone were present. The following table summarizes our findings : 


\begin{tabular}{|c|c|c|c|c|c|c|}
\hline Case. & Age. & Sex. & $\begin{array}{l}\text { General } \\
\text { bealth. }\end{array}$ & Vision. & $\begin{array}{c}\text { Type of corneal } \\
\text { lesion, classification } \\
\text { according to Graves. }\end{array}$ & $\begin{array}{l}\text { Other ocular } \\
\text { findings. }\end{array}$ \\
\hline $121 \mathrm{~A}$ & 42 & F. & $\begin{array}{l}\text { Approaching } \\
\text { menopause. } \\
\text { H y pert e n- } \\
\text { sion(156/90). } \\
\text { Oral sepsis }\end{array}$ & $\begin{array}{l}\text { R 20/15 } \\
\text { L 20/19 }\end{array}$ & $\begin{array}{l}\text { No lesion } \\
\text { III.-A. At first } \\
\text { no pigment. Six } \\
\text { months later a few } \\
\text { fine pigment gran- } \\
\text { ules near centre } \\
\text { of cornea. Epi- } \\
\text { thelium perfectly } \\
\text { normal. }\end{array}$ & $\begin{array}{l}\text { None } \\
\text { Few granules of } \\
\text { pigment on an- } \\
\text { terior surface of } \\
\text { lens. Few very } \\
\text { fine opacities in } \\
\text { anterior part of the } \\
\text { vitreous }\end{array}$ \\
\hline 1416A & 77 & F. & $\begin{array}{l}\text { Generalized } \\
\text { arterioscler- } \\
\text { osis }\end{array}$ & R 20/38 & $\begin{array}{l}\text { III.-A. Ver y } \\
\text { few pigment gran- } \\
\text { ules near centre }\end{array}$ & $\begin{array}{l}\text { Marked arcus } \\
\text { senilis. Slight } \\
\text { sclerosis of lens } \\
\text { nucleus; slight } \\
\text { rise in intraocular } \\
\text { tension five years } \\
\text { ago, controlled by } \\
\text { miotics }\end{array}$ \\
\hline & & & & L 20/60 & $\begin{array}{l}\text { III._-A. M ore } \\
\text { pigment }\end{array}$ & $\begin{array}{l}\text { Marked arcus } \\
\text { senilis. Moderate } \\
\text { sclerosis of lens } \\
\text { nucleus; s lig t t } \\
\text { rise in intraocular } \\
\text { tension six years } \\
\text { ago, controlled by } \\
\text { iridectomy. }\end{array}$ \\
\hline 67382 & 42 & F. & Obesity & $\begin{array}{l}\text { R } 20 / 30 \\
\text { L } 20 / 30\end{array}$ & $\begin{array}{l}\text { III.-B. No pig- } \\
\text { ment. } \\
\text { III.-B. No pig- } \\
\text { ment }\end{array}$ & $\begin{array}{l}\text { Neg. } \\
\text { Neg. }\end{array}$ \\
\hline $2332 \mathrm{~A}$ & 61 & F. & $\begin{array}{l}\text { History of } \\
\text { thyroid en- } \\
\text { largement. } \\
\text { Slightly ele- } \\
\text { vated blood } \\
\text { pressure }\end{array}$ & $\begin{array}{l}\text { R 20/15 } \\
\text { L 20/19 }\end{array}$ & $\begin{array}{l}\text { III.-A. No pig- } \\
\text { ment } \\
\text { III.-A. No pig- } \\
\text { ment }\end{array}$ & $\begin{array}{l}\text { Neg. } \\
\text { Neg. }\end{array}$ \\
\hline 29279 & 55 & F. & $\begin{array}{l}\text { High blood } \\
\text { pressure }\end{array}$ & $\begin{array}{l}\text { R 20/24 } \\
\text { L 20/24 }\end{array}$ & $\begin{array}{l}\text { III.-A. F e w } \\
\text { pigment granules } \\
\text { III.-A. M ore } \\
\text { pigment }\end{array}$ & $\begin{array}{l}\text { Neg. } \\
\text { Neg }\end{array}$ \\
\hline
\end{tabular}

\section{Comment on Group I}

To summarize the above table, we have noted the condition described in five cases, all women over forty. No general or local disease seemed specifically related to the picture. Two of these cases have been followed for over three years, during which time no change could be observed. It is interesting to note that one of the cases, the last in the above table, was first seen eight years ago, before the use of the slit-lamp corneal microscope. At that time a fine granular haze in the anterior portion of the eyes was noted, but it was not possible definitely to localize this haze. 


\section{Group II.-Cases of dystrophia epithelialis corneae}

Case 1: Miss E., No. 20372, aged 72 years, has always enjoyed good health. She was first seen 18 years ago, at which time she complained of eye strain. With correcting glasses her vision was perfect in each eye and no lesions were found. She was seen at intervals of two or three years and no changes noted until 1916, ten years after the first examination, when her vision had become slightly blurred (from 20/15 it became 20/19), and a fine dusty opacity was noted which could be seen only with the ophthalmoscope with high plus lenses and was thought to be located in the lens. Subsequent observations make it seem likely that this haze was corneal and not lenticular. General physical examination at that time was negative.

During the next two years the condition was practically stationary, but a year later, in 1919, she complained of occasional stinging pain in her eyes. Her vision was now $20 / 30$ in each eye, and there was easily visible a diffuse haze of the lower half of each cornea. The corneal surface was roughened, and small blebs were present under the epithelium. Since that time the vision has fluctuated slightly, the corneal haze has become much more dense, but has not extended very much farther. There is no loss of sensibility of the cornea. The treatment has consisted of occasional courses of dionin.

Since 1.922 this case has been repeatedly studied with the corneal microscope. The area of densest haze extends from slightly above the centre of the cornea almost to the lower limbus. Over this area the epithelium is roughened, lacking in lustre and considerably thickened. It has lost much of its normal transparency. Here and there it is elevated over small irregular accumulations of clear fluid. These blebs at times reach $0.5 \mathrm{~mm}$. in diameter, but for the most part they are much smaller. Occasionally one sees a small crater-like depression in the epithelium suggesting that here one of the blebs has burst. The stroma beneath the affected epithelium is somewhat thickened and shows a diffuse haze most intense in the superficial layers. Roughly about one-half the total opacity of the cornea here may be laid to the epithelial change, half to the change in the stroma. The deepest layers of the cornea cannot be clearly seen in this region, but certainly they contain no considerable accumulations of pigment and no very dense opacities.

Near the border of the dense epithelial opacity it is possible, by looking obliquely through the cornea beneath the affected epithelium, to get a fairly good view of the deeper layers. The endothelial surface here is seen to be thrown into innumerable minute irregular confluent elevations such as $\mathrm{Mr}$. Graves has described in his type III-B. On direct illumination one sees here great numbers of tiny golden yellow straight and curved lines 
suggesting pigment deposits, but on retro-illumination only a few scattered pigment granules can be seen. This area of great irregularity in the endothelial surface has a fairly sharp border, corresponding more or less to the border of the epithelial change, but beyond this and extending nearly to the limbus the endothelium is closely studded with minute dew-drop-like elevations. In the clear part of the stroma the corneal nerves can be well seen but do not appear abnormal. The iris and lens show no abnormality. Visual fields and intraocular tension are normal. The patient's general health remains excellent.

Case 2. Mr. T, No. 488-A, aged 58 years, has always enjoyed good health. He was first seen a year and a half ago when he complained that the vision of his right eye was sometimes blurred, especially in the morning. Vision, with proper correction : R.E. $=20 / 38 ;$ L.E. $=20 / 15$. There is a diffuse opacity occupying the lower two-thirds of the right cornea, not quite reaching the limbus. The epithelium and stroma in this'region show quite the same changes as those described in Case 1. The endothelial surface, so far as it can be seen, is studded with minute clear dewdrop elevations, but is in addition thrown into numerous coarser vertical folds or corrugations.

The left cornea shows no epithelial lesions even on careful examination. The stroma appears quite normal. The endothelial surface presents a picture identical with that in the right eye; only one tiny dot of pigment was found in this cornea.

Both eyes showed only slight arcus senilis. The capillaries of the conjunctiva and the corneal nerves did not appear abnormal. The iris, lens, and fundus of each eye, so far as they could be seen were quite normal. Visual fields normal.

The patient was subjected to a careful general physical examination which revealed nothing of significance. There were a few abscessed teeth, which were removed, and slight gastric hyperacidity. During the summer of 1924, the patient suffered from a series of boils and styes and was treated with autogenous vaccine. The patient has been under observation at frequent intervals for a year and a half during which time there seems to have been little change in his condition.

Case 3. Mrs. W., No. 63122, aged 67 years, had always enjoyed good health until within the last few years. In 1919 she suffered with headaches and nervousness due to hyperthyroidism and in 1920 her thyroid was partially removed. In 1922, after several attacks of gallstone colic, her gall-bladder and many gallstones were removed. The urine has a trace of albumen and a few hyalin casts; no sugar. She first came under observation in 1920 , when she complained of a blur before her eyes. With correction of her quite considerable astigmatism the central vision was very good 
in each eye $(20 / 19)$, but the ophthalmoscopic picture was found to be slightly blurred due to a fine dust-like haze in both corneae. This haze was not located in the epithelium which was noted to be smooth and glistening. There has been some fluctuation in the patient's condition since that time, but on the whole a steady slow increase of the corneal trouble and a decrease in the visual acuity which, at the last examination in October, 1924, was $20 / 38$.

The patient was first examined with the corneal microscope in 1922 , when it was noted that the epithelium of the right cornea was slightly roughened and hazy in the central area. In the epithelium of the left cornea no lesion could be found. The inner surface of both corneae, however, was closely studded with small rounded elevations.

In June, 1924, there was seen a diffuse haze in the epithelium of the central areas of both corneae, with small accumulations of fluid under the epithelium and the complete picture of epithelial dystrophy. The endothelium has in the meanwhile remained unchanged. The iris, lens, fundus, and visual field of each eve were at all times normal.

\section{Discussion}

It has been our aim in reporting together these two groups of cases, and in giving the detailed history of the cases of epithelial dystrophy observed over a period of some years, to illustrate the relationship which we believe exists between the changes in the corneal endothelium and the epithelial dystrophy described by Fuchs. The presence of endothelial changes in cases of corneal dystrophy has been noted both by Kraupa ${ }^{(12)}$ and by Vogt ${ }^{(13)}$. As far as these observations go they are in agreement with our own, excepting that these writers regard the deposits on Descemet's membrane as pigmented. It is true that on direct illumination a brilliant golden sheen is observed simulating pigment, but on retro-illumination only a few pigment granules are seen. The picture has been very aptly described by $\operatorname{Vogt}^{(13)}$. It is as if "powdered bronze had been dusted over the back of the cornea." With such agreement in description there can be no doubt that the picture seen by him and by us is the same.

The point which we desire to emphasize, however, is not merely that endothelial changes are present in cases of corneal dystrophy, but that in one of our cases (Case 3) the endothelial changes clearly preceded those in the epithelium, while in the other two of our cases, there is excellent presumptive evidence that the same course of events took place.

The endothelial changes seen in our cases of dystrophy are identical with the endothelial changes in cases without dystrophy. These facts would indicate that the endothelial changes, and the 
epithelial dystrophy of Fuchs, are not separate disease entities, but are to be considered together as the beginning and the end of a single disease process, though undoubtedly, the rate of progress of the disease is so slow that many cases fail ever to advance beyond the early stages.

The histology of the changes in the epithelium and stroma has been studied by Fuchs and Uhthoff(11) in small bits of tissue excised with a trephine, but the histology of the endothelial changes has not as yet been investigated. The appearance under examination with the corneal microscope strongly suggests, as has been pointed out by Vogt, that the elevations of the endothelial surface are due to structure similar to the "drusen" or Henle warts of Descemet's membrane, which are so commonly found in the periphery of the cornea in elderly persons.

No light has as yet been thrown on the aetiology of this peculiar condition. Whether the epithelial changes result from the injury of the endothelium or whether both result from some other cause would seem in the present state of our knowledge an academic question. The fact that the endothelial changes can exist for years before the epithelial changes develop would point, perhaps, to some other, as yet unknown factor, as cause for the whole disease process.

\section{BIBLIOGRAPHY}

1. Fuchs.-Dystrophia Epithelialís Corneae. Arch.f. Ophthal., Vol. LXXVI, p. 478, 1910. Reports 13 cases, four men, nine women. Average age of onset 58 years. Fluctuations in visual acuity-usually worse in the morning-but generally slow progress of lesion. Diminution in corneal sensibility noted. The condition is frequently associated with glaucoma but is not glaucomatous. Usually bilateral but occasionally it is unilateral. Histological examination of tissue removed with a trephine shows new formed connective tissue between Bowman's membrane and the epithelium.

2. Paul Knapp.-Kasuistischer Beitrag zu der "Dystrophia Epithelialis Corneae nach Fuchs." Arch.f. Ophthal., Vol. LXXVIII, p. 331, 1911. Reports one case.

3. Troncosco.-Epithelial Dystrophy of the Cornea. Amer. Jl. Ophthal., Vol XXI, p. 369, 1912. Reports one case.

4. Reese.-Dystrophia Epithelialis Corneae. Ophthal. Rec., Vol. XXII, p. 131, 1913. Arch. of Ophthal., Vol. XLIII, p. 57, 1914. Reports one case.

5. Whitham.-Dystrophia Epithelialis Corneae. Bull. Johns Hopkins Hosp., Vol. XXV, p. 156, 1914. Reports one case complicated by diabetes.

6. Clegg.-Dystrophies of the Cornea and Glaucoma. Trans. Ophthal. Soc. U.K., April, 1915, Arch. of Ophth., Vol. XLIV, p. 577, 1915. Reports familial group of cases, some complicated by glaucoma.

7. Fuchs.-Erkrankung der Hornhaut durch Schaedigung von innen. Arch. $f$, Ophthal., Vol. XCII. p. 208, 1916. Dystrophia epithelialis may lead to sclerosis of the cornea.

8. Posey.-An unusual form of Superficial Corneal Opacity, probably an instance of Atypical Epithelial Dystrophy. Arch. of Ophthal., Vol. XLVI, p. 113, 1917. Reports one case quite unlike the cases described by Fuchs.

9. Koeppe.-Klinische Beobachtungen mit der Nernstspaltlampe und dem Hornhautmikroskop. Arch. f. Ophthal., Vol. XCIV., p. 250, 1917. Evidently describing a different condition, for he says it is found in very degenerated eyes " mit chronischer Iridocyclitis und Glaucom behaftet." 
10. Zentmayer.-Epithelial Dystrophy of the Cornea. Amer. Jl. of Ophthal., Vol. I, p. 450,1918 . Reports one case.

11. Uhthoff.-Anatomische Untersuchungen zur Hornhaut und Bindehautdegeneration: a. Dystrophia Cornealis Epithelialis (Fuchs). Deutsch Ophthal. Gesell., Heidelberg XLII, p. 308 1920. Superficial layers of corneal epitbelium show swelling and irregularity. Some superficial cells have lost their nuclei and are markedly flattened out, elongated. Basal cells relatively normal. Bowman's § membrane absent. The superficial layers of corneal stroma are degenerated and show oedematous swellings.

12. Kraupa.-Pigmentierung des Hornhauthinterflaeche bei Dystrophia Epithelialis. Zeitschr. f. Augenheilk., Vol. XLIV, p. 247, 1920. Reports four cases of $\bar{\omega}$ epithelial dystrophy with brown needle-like glittering crystals under the $ᄋ$ endothelium. Regards the corneal dystrophy as depending upon the endothelial $\frac{O}{O}$ injury.

13. Vogt. - Weitere Ergebnisse der Spaltlampenmikroskopie des vorderen Bulbusab. schnittes. Arch. f. Ophthal., Vol. CVI, p, 63, 1921. Reports two cases: observed with the corneal microscope. Describes endothelial changes as golden yellow crystalline pigment granules. Suggests that the endothelial changes may precede those in the epithelium. Describes droplike elevations of the endothelial surface in elderly persons sometimes combined with pigment deposits. He considers the prominences as being Henle warts of Descemet's membrane.

14. Moeschler.--Untersuchungen ueber Pigmentierung der Hornhautrueckflaeche. Zeitsch. f. Augenheilk, Vol. XLVIII, p. 195, 1922. 94 persons over 50 with 176 eyes showed eight eyes with " tropfige Endothelprominenzen."

15. Graves.-A Bilateral Chronic Affection of Endothelial Face of the Cornea. Brit. Jl. of Ophthal., Vol. VIII, p. 502, 1924. Describes the following types: I. Few N elevations of endothelium at the centre of the cornea. II. More numerous elevations still limited to the centre of the cornea. III. $a$. Uniform distribution of elevations over a large part of the cornea $b$. Rounded discrete elevations in the periphery of the cornea with more complicated changes in the central area. IV. Same as type III with the additional appearance of transitory vacuoles in the epithelium.

\section{AN UNCOMMON LUXATION OF THE LENS}

BY

$$
\text { J. S. Steijn, M.D., }
$$

CHIEF ASSISTANT, UNIVERSITY EYE CLINIC, GRONINGEN (DIRECTOR, PROF. DR. G. F. ROCHAT).

OCULISTS are well aware of the fact that after a blunt injury to the eye the lens may be luxated : either disappearing in the vitreous or entering the anterior chamber, or even escaping altogether from the eye through a rupture in the sclera. But I have never heard of a lens being completely reversed as in the following case.

An old woman came to the clinic complaining of severe pain in and above the right eye. She informed me that thirteen years ago she had a severe blow on the eye with a broomstick, and that the eye was blind since then, but that it had never given her any discomfort until three days ago.

In the anterior chamber a yellowish lens-shaped mass could be seen, nearly filling the whole chamber.

Examined with the slit-lamp, its surface, lying against the posterior surface of the cornea, showed a peculiar woolly appearance, closely resembling a small powder puff. It was taken for an 